\title{
The dilemma of cultivated hepatocytes
}

\author{
J. G. Hengstler $\cdot$ P. Godoy $\cdot$ H. M. Bolt
}

Published online: 28 January 2009

(C) Springer-Verlag 2009

Isolated and cultivated primary hepatocytes represent a frequently used in vitro system for studies of drug metabolism, enzyme induction and hepatotoxicity (Hewitt et al. 2007; Sinha et al. 2007; Lee et al. 2007; Ullrich et al. 2007; Carmo et al. 2005; Parody et al. 2007; Magdalan et al. 2009). An additional relatively new field of application is analysis of gene expression patterns in cultured hepatocytes (Muguruma et al. 2008; Thum and Borlak 2008; Schug et al. 2008; Tuschl and Mueller 2006). Major limitations are limited availability for human hepatocytes and the relatively fast dedifferentiation of cultured rodent hepatocytes. Establishment of cryopreservation techniques has improved the availability of human hepatocytes but still the situation is not fully satisfactory, because some hepatocellular functions decrease due to the freezing and thawing procedure (Hengstler et al. 2000; Kafert-Kasting et al. 2006; Gebhardt et al. 2003). Well-known strategies to reduce dedifferentiation of rodent hepatocytes are the cultivation in threedimensional systems, such as collagen sandwiches or alginate beads (Hewitt et al. 2007; Ringel et al. 2005; Schug et al. 2008), hormonal additives as well as epigenetic modulators (Ringel et al. 2002; Snykers et al. 2007). However, to which degree all in vivo like functions of hepatocytes can be maintained by these techniques remains to be demonstrated by genome wide analyses in combination with functional tests. Unfortunately, one of the most promising approaches, differentiation of an unlimited supply of human hepatocytes from stem and precursor cells has not yet succeeded in generating fully differentiated hepatocytes

J. G. Hengstler $(\bowtie) \cdot$ P. Godoy · H. M. Bolt Leibniz-Institut für Arbeitsforschung an der TU Dortmund, Leibniz Research Centre for Working Environment and Human Factors (IfADo), Ardeystrasse 67, 44139 Dortmund, Germany e-mail: hengstler@ifado.de
(Hengstler et al. 2005; Nussler et al. 2006; Brulport et al. 2007; Aurich et al. 2007; Ruhnke et al. 2005a, b). One of the most amazing limitations is the failure to achieve an efficient proliferation (and re-differentiation) of human hepatocytes in vitro, although hepatocytes have an excellent proliferation capacity in vivo after hepatectomy or regeneration from toxic liver damage (Höhme et al. 2007; Klingmüller et al. 2006). These limitations led to a situation where despite of their known dedifferentiation human hepatoma cell lines are still used in toxicity testing (O'Brien et al. 2006; Westerink et al. 2008; Bauer et al. 2006; Nagashima et al. 2007; Skupinska et al. 2007) instead of the better but limited primary human hepatocytes. Because rodent hepatocytes dedifferentiate in vitro still many scientists prefer in vivo hepatotoxicity testing to in vitro systems (Spicker et al. 2007; Franc et al. 2008; Abe et al. 2008; Chou et al. 2008; Nishimura et al. 2008; Chan et al. 2008). What may be a way of overcoming this dilemma? In brief: more thorough basic research and less alchemy. Research in the field of hepatocyte in vitro systems has suffered from "trial and error" approaches aimed at improving hepatocellular functions without knowing the responsible mechanisms. We first need to understand which signalling pathways or signalling network constellations promote hepatocyte dedifferentiation. Which are the critical transcription factors? Which signalling pathways and mechanisms are active in proliferating hepatocytes in vivo but can not sufficiently be activated in vitro to achieve cell cycle progression? We should realize that it represents a "mission impossible" to manipulate stem cells in vitro to form a cell type as complex as a fully differentiated hepatocyte, when we do not even know the critical factors to maintain the differentiated state of cultured primary hepatocytes. Based on this still missing knowledge the responsible mechanisms could specifically be modified by numerous strategies ranging 
from small molecules and siRNA to support by specific components of the extracellular matrix and 3D culture systems. An important aspect will be genome wide characterization of gene expression patterns and comparison to tissues ex vivo. Selection of just a few markers may lead to biased conclusions. Since the mechanisms switching hepatocytes between a differentiated, a dedifferentiated as well as a proliferating state are not yet fully known, a fast and easy way out of the dilemma is unlikely. However, understanding the mechanisms is the only promising strategy.

\section{References}

Abe M, Usuda K, Hayashi S, Ogawa I, Furukawa S, Igarashi M, Nakae D (2008) Carcinogenic risk of copper gluconate evaluated by a rat medium-term liver carcinogenicity bioassay protocol. Arch Toxicol 82:563-571

Aurich I, Mueller LP, Aurich H, Luetzkendorf J, Tisljar K, Dollinger MM, Schormann W, Walldorf J, Hengstler JG, Fleig WE, Christ B (2007) Functional integration of hepatocytes derived from human mesenchymal stem cells into mouse livers. Gut 56:405415

Bauer M, Herbarth O, Aust G, Hengstler JG, Dotzauer A, Graebsch C, Schmuecking E (2006) Expression patterns and novel splicing variants of glutathione- $S$-transferase isoenzymes of human lung and hepatocyte cell lines. Cell Tissue Res 324:423-432

Brulport M, Schormann W, Bauer A, Hermes M, Elsner C, Hammersen FJ, Beerheide W, Spitkovsky D, Härtig W, Nussler A, Horn LC, Edelmann J, Pelz-Ackermann O, Petersen J, Kamprad M, von Mach M, Lupp A, Zulewski H, Hengstler JG (2007) Fate of extrahepatic human stem and precursor cells after transplantation into mouse livers. Hepatology 46:861-870

Carmo H, Hengstler JG, de Boer D, Ringel M, Remião F, Carvalho F, Fernandes E, dos Reys LA, Oesch F, de Lourdes Bastos M (2005) Metabolic pathways of 4-bromo-2, 5-dimethoxyphenethylamine (2C-B): analysis of phase I metabolism with hepatocytes of six species including human. Toxicology 206:75-89

Chan PC, Sills RC, Kissling GE, Nyska A, Richter W (2008) Induction of thyroid and liver tumors by chronic exposure to 2-methylimidazole in F344/N rats and B6C3F1 mice. Arch Toxicol 82:399-412

Chou CP, Lu SY, Ueng TH (2008) Modulation of serum concentrations and hepatic metabolism of 17beta-estradiol and testosterone by amitraz in rats. Arch Toxicol 82:729-737

Franc MA, Moffat ID, Boutros PC, Tuomisto JT, Tuomisto J, Pohjanvirta R, Okey AB (2008) Patterns of dioxin-altered mRNA expression in livers of dioxin-sensitive versus dioxin-resistant rats. Arch Toxicol 82:809-830

Gebhardt R, Hengstler JG, Müller D, Glöckner R, Buenning P, Laube B, Schmelzer E, Ullrich M, Utesch D, Hewitt N, Ringel M, Hilz BR, Bader A, Langsch A, Koose T, Burger HJ, Maas J, Oesch F (2003) New hepatocyte in vitro systems for drug metabolism: metabolic capacity and recommendations for application in basic research and drug development, standard operation procedures. Drug Metab Rev 35:145-213

Hengstler JG, Utesch D, Steinberg P, Platt KL, Diener B, Ringel M, Swales N, Fischer T, Biefang K, Gerl M, Böttger T, Oesch F (2000) Cryopreserved primary hepatocytes as a constantly available in vitro model for the evaluation of human and animal drug metabolism and enzyme induction. Drug Metab Rev 32:81-118

Hengstler JG, Brulport M, Schormann W, Bauer A, Hermes M, Nussler AK, Fandrich F, Ruhnke M, Ungefroren H, Griffin L,
Bockamp E, Oesch F, von Mach MA (2005) Generation of human hepatocytes by stem cell technology: definition of the hepatocyte. Expert Opin Drug Metab Toxicol 1:61-74

Hewitt NJ, Lechón MJ, Houston JB, Hallifax D, Brown HS, Maurel P, Kenna JG, Gustavsson L, Lohmann C, Skonberg C, Guillouzo A, Tuschl G, Li AP, LeCluyse E, Groothuis GM, Hengstler JG (2007) Primary hepatocytes: current understanding of the regulation of metabolic enzymes and transporter proteins, and pharmaceutical practice for the use of hepatocytes in metabolism, enzyme induction, transporter, clearance, and hepatotoxicity studies. Drug Metab Rev 39:159-234

Höhme S, Hengstler JG, Brulport M, Schäfer M, Bauer A, Gebhardt R, Drasdo D (2007) Mathematical modelling of liver regeneration after intoxication with $\mathrm{CCl}(4)$. Chem Biol Interact 168:74-93

Kafert-Kasting S, Alexandrova K, Barthold M, Laube B, Friedrich G, Arseniev L, Hengstler JG (2006) Enzyme induction in cryopreserved human hepatocyte cultures. Toxicology 220:117-125

Klingmüller U, Bauer A, Bohl S, Nickel PJ, Breitkopf K, Dooley S, Zellmer S, Kern C, Merfort I, Sparna T, Donauer J, Walz G, Geyer M, Kreutz C, Hermes M, Götschel F, Hecht A, Walter D, Egger L, Neubert K, Borner C, Brulport M, Schormann W, Sauer C, Baumann F, Preiss R, MacNelly S, Godoy P, Wiercinska E, Ciuclan L, Edelmann J, Zeilinger K, Heinrich M, Zanger UM, Gebhardt R, Maiwald T, Heinrich R, Timmer J, von Weizsäcker F, Hengstler JG (2006) Primary mouse hepatocytes for systems biology approaches: a standardized in vitro system for modelling of signal transduction pathways. Syst Biol (Stevenage) 153:433447

Lee HS, Jung SH, Yun BS, Lee KW (2007) Isolation of chebulic acid from Terminalia chebula Retz. and its antioxidant effect in isolated rat hepatocytes. Arch Toxicol 81:211-218

Magdalan J, Ostrowska A, Podhorska-Okołów M, Piotrowska A, Izykowska I, Nowak M, Dolińska-Krajewska B, Zabel M, Szelag A, Dziegiel P (2009) Early morphological and functional alterations in canine hepatocytes due to alpha-amanitin, a major toxin of Amanita phalloides. Arch Toxicol 83(1):55-60

Muguruma M, Arai K, Moto M, Nishimura J, Dewa Y, Mitsumori K (2008) Piperonyl butoxide activates c-Jun and ATF-2 in the hepatocytes of mice. Arch Toxicol 82:749-753

Nagashima H, Maeda-Nakamura K, Iwashita K, Goto T (2007) Induced secretion of insulin-like growth factor binding protein-1 (IGFBP-1) in human hepatoma cell HepG2 by rubratoxin B. Arch Toxicol 81:347-351

Nishimura J, Dewa Y, Okamura T, Muguruma M, Jin M, Saegusa Y, Umemura T, Mitsumori K (2008) Possible involvement of oxidative stress in fenofibrate-induced hepatocarcinogenesis in rats. Arch Toxicol 82:641-654

Nussler A, Konig S, Ott M, Sokal E, Christ B, Thasler W, Brulport M, Gabelein G, Schormann W, Schulze M, Ellis E, Kraemer M, Nocken F, Fleig W, Manns M, Strom SC, Hengstler JG (2006) Present status and perspectives of cell-based therapies for liver diseases. J Hepatol 45:144-159

O'Brien PJ, Irwin W, Diaz D, Howard-Cofield E, Krejsa CM, Slaughter MR, Gao B, Kaludercic N, Angeline A, Bernardi P, Brain P, Hougham C (2006) High concordance of drug-induced human hepatotoxicity with in vitro cytotoxicity measured in a novel cell-based model using high content screening. Arch Toxicol 80:580-604

Parody JP, Alvarez Mde L, Quiroga A, Ronco MT, Francés D, Carnovale C, Carrillo MC (2007) Hepatocytes isolated from preneoplastic rat livers are resistant to ethacrynic acid cytotoxicity. Arch Toxicol 81:565-573

Ringel M, Oesch F, Gerl M, Klebach M, Quint M, Bader A, Böttger T, Hengstler JG (2002) Permissive and suppressive effects of dexamethasone on enzyme induction in hepatocyte co-cultures. Xenobiotica 32:653-666 
Ringel M, von Mach MA, Santos R, Feilen PJ, Brulport M, Hermes M, Bauer AW, Schormann W, Tanner B, Schön MR, Oesch F, Hengstler JG (2005) Hepatocytes cultured in alginate microspheres: an optimized technique to study enzyme induction. Toxicology 206:153-167

Ruhnke M, Ungefroren H, Nussler A, Martin F, Brulport M, Schormann W, Hengstler JG, Klapper W, Ulrichs K, Hutchinson JA, Soria B, Parwaresch RM, Heeckt P, Kremer B, Fändrich F (2005a) Differentiation of in vitro-modified human peripheral blood monocytes into hepatocyte-like and pancreatic islet-like cells. Gastroenterology 128:1774-1786

Ruhnke M, Nussler AK, Ungefroren H, Hengstler JG, Kremer B, Hoeckh W, Gottwald T, Heeckt P, Fandrich F (2005b) Human monocyte-derived neohepatocytes: a promising alternative to primary human hepatocytes for autologous cell therapy. Transplantation 79:1097-1103

Schug M, Heise T, Bauer A, Storm D, Blaszkewicz M, Bedawy E, Brulport M, Geppert B, Hermes M, Föllmann W, Rapp K, Maccoux L, Schormann W, Appel KE, Oberemm A, GundertRemy U, Hengstler JG (2008) Primary rat hepatocytes as in vitro system for gene expression studies: comparison of sandwich, Matrigel and 2D cultures. Arch Toxicol 82:923-931

Sinha M, Manna P, Sil PC (2007) Attenuation of cadmium chloride induced cytotoxicity in murine hepatocytes by a protein isolated from the leaves of the herb Cajanus indicus L. Arch Toxicol 81:397-406

Skupinska K, Misiewicz I, Kasprzycka-Guttman T (2007) A comparison of the concentration-effect relationships of PAHs on CYP1A induction in HepG2 and Mcf7 cells. Arch Toxicol 81:183-200

Snykers S, Vinken M, Rogiers V, Vanhaecke T (2007) Differential role of epigenetic modulators in malignant and normal stem cells: a novel tool in preclinical in vitro toxicology and clinical therapy. Arch Toxicol 81:533-544

Spicker JS, Pedersen HT, Nielsen HB, Brunak S (2007) Analysis of cell death inducing compounds. Arch Toxicol 81:803-811

Thum T, Borlak J (2008) Detection of early signals of hepatotoxicity by gene expression profiling studies with cultures of metabolically competent human hepatocytes. Arch Toxicol 82:89-101

Tuschl G, Mueller SO (2006) Effects of cell culture conditions on primary rat hepatocytes-cell morphology and differential gene expression. Toxicology 218:205-215

Ullrich A, Berg C, Hengstler JG, Runge D (2007) Use of a standardised and validated long-term human hepatocyte culture system for repetitive analyses of drugs: repeated administrations of acetaminophen reduces albumin and urea secretion. ALTEX 24:35-40

Westerink WM, Stevenson JC, Schoonen WG (2008) Pharmacologic profiling of human and rat cytochrome P450 1A1 and 1A2 induction and competition. Arch Toxicol 82:909-921 